\title{
Communication/Comunicação
}

\section{Acetylcholinesterase inhibition starting from extracts of Bauhinia variegata L., Bauhinia var. candida (Aiton) Buch.-Ham., and Bauhinia ungulata $L$}

\author{
Inibição de acetilcolinesterase a partir de extratos de Bauhinia variegata L., Bauhinia variegata \\ var. candida (Aiton) Buch.-Ham., e Bauhinia ungulata $\mathrm{L}$
}

Kamilla Monteiro dos Santos ${ }^{1}$, Priscila Sant'Ana Gonçalves ${ }^{1}$, Maria José Nunes de Paiva ${ }^{2}$ and Guilherme Araújo Lacerda ${ }^{1}$

\begin{abstract}
Introduction: A treatment to the Alzheimer's disease consists inhibition of the acetylcholinesterase, which is responsible for the acetylcholine control in the synapses. Methods: We have investigated the potential of inhibition of the acetylcholinesterase produced by hexane extracts of leaves, branches, and flowers from three Bauhinia specimens, which is based on the technique of thin layer chromatography and on identifying the organ of the plant that possesses larger concentration of inhibitors. Results: Retention factor analysis shows values of $0.31 \mathrm{aA}, 0.31 \mathrm{aA}$, and $0.46 \mathrm{aB}$ for flowers $B$. variegata, B. var. candida, and B. ungulata, respectively. Conclusions: The flower extract of $B$. ungulata is the most suitable for further studies on this inhibition.
\end{abstract}

Keywords: Acetylcholinesterase. Bauhinia. Chromatography.

\section{RESUMO}

Introdução: Um tratamento para a doença de Alzheimer consiste na inibição da acetilcolinesterase, responsável pelo controle de acetilcolina nas sinapses. Métodos: Nós investigamos o potencial de inibição da acetilcolinesterase produzido por extratos hexânicos de folhas, ramos e flores de três espécimes de Bauhinia, realizado a partir da cromatografia em camada delgada e que órgão possui maior concentração de inibidores. Resultados: Os fatores de retenção apresentaram $0,31 \mathrm{aA}, 0,31 \mathrm{aA}$ e $0,46 \mathrm{aB}$ para as flores de $B$. variegata, $B$. var. candida e $B$. ungulata respectivamente. Conclusões: $\mathrm{O}$ extrato de flores de B. ungulata é o mais satisfatório para futuros estudos desta inibição. Palavras-chave: Acetilcolinesterase. Bauhinia. Cromatografia.

Alzheimer's disease $(\mathrm{AD})$ has reached about 20 million people worldwide, and this index is only set to grow due to the increasing life expectancy that has been observed in recent years. This disease is characterized by affecting the short-term memory and associative cortical areas; thus, the carrier of $\mathrm{AD}$ needs permanent care and stress, psychological, and financial support from family caregivers ${ }^{1}$.

It is believed that the pathophysiology of $\mathrm{AD}$ is related to the presence of senile plaques and neurofibrillary tangles, the beadvacuolar degeneration, and neuronal loss. At cellular levels, $\mathrm{AD}$ is related mainly to a decrease of acetylcholine (Ach) in the synaptic cleft, so several cholinomimetic therapies have been tested for the treatment of $\mathrm{AD}$; however, more effective effects could be verified by treatments that lead to the inhibition of acetylcholinesterase $(\mathrm{AChE})^{2}$.

1. Faculdade de Biomedicina, Universidade José do Rosário Vellano, Divinópolis, MG. 2. Faculdade de Farmácia, Campus Dona Lindu, Universidade Federal de São João Del Rei, Divinópolis, MG.

Address to: Mestranda Kamilla Monteiro dos Santos. Faculdade Biomedicina/UNIFENAS Rua Tedinho Alvim 100, Bairro Liberdade, 35502-634 Divinópolis, MG, Brasil. Phone: 5537 3212-7888

e-mail: kamillamonteiro7@hotmail.com

Received in 04/10/2010

Accepted in 13/05/2011
The use of medicinal plants is one of the oldest practices carried out by man and is still very widespread today. Currently, many people and health professionals choose to perform therapies with these plants as complements to the treatments based on synthetic ${ }^{3}$. The species of the genus Bauhinia, endemic to cerrado biome, are used by the population and are being considered primarily as antihyperglycemic adaptogenic. Known as Pata-de-vaca (Orchid tree), these species are also found in street trees and have compounds that are interesting medicinally $y^{4}$. Due to these characteristics, these species represent examples that have the potential inhibition of acetylcholinesterase, and thus, according to the results, these could assist in the treatment of $\mathrm{AD}$.

We collected leaves, flowers, and branches of Bauhinia ungulata, Bauhinia variegata, and Bauhinia variegata candida from single trees in the following locations: at the Jovelino Rabelo street, next to number 530 in Porto Velho, Divinópolis, MG; at the Jovelino Rabelo street, next to number 530 in the same neighborhood in Divinópolis, MG; and at the Maestro João Pinto street, in the home of number 85 in the Esplanada in Divinópolis, MG, Brazil.

The samples were washed, chopped, and dried in an oven at $45^{\circ} \mathrm{C}$ for 5 days. They were then crushed in a blender ${ }^{5}$. These samples were also prepared to be the dried specimens and subsequently deposited in the herbarium of the Universidade José do Rosário Vellano (UNIFENAS), Divinópolis campus; identified by Professor Doctor Guilherme Araújo Lacerda CRBio 44480/04-D; and cataloged by the numbers: Bauhinia ungulata L. 024, Bauhinia variegata L. 025, and Bauhinia variegata candida (Aiton) Buch-Ham 026.

According to technique adapted from Souza ${ }^{6}, 116 \mathrm{~g}$ of each dried sample were added to $1 \mathrm{~L}$ of hexane in glass jars capped and covered with brown paper. The flasks were shaken mechanically for $10 \mathrm{~min}$ and were then left to stand for $72 \mathrm{~h}$ for maceration. The macerate was vacuum-filtered, and the solvent was extracted by distillation and water-bathed at $60^{\circ} \mathrm{C}$.

For the analysis of acetylcholinesterase inhibition, thin layer chromatography (TLC) was used as recommended by Moraes², with some adaptations.

The TLCs were performed in duplicate. In each plate of silica gel, were applied to extracts of species of Bauhinia, grouped according to plant part investigated. Then the plates were developed in the system $n$-hexane-acetone $(80: 20)$ in tanks previously saturated until $0.5 \mathrm{~cm}$ of silica final. After the run, the plates were air-dried and received nebulized solution of $\mathrm{N}$-bromosuccinimide. Excess oxidant was removed under a stream of hot air for $20 \mathrm{~min}$, and then, the solution was nebulized with cholinesterases. After $20 \mathrm{~min}$, the 
solution of 2-naphthyl acetate was sprayed with fast blue B, and the chromogenic analysis was performed after 30 mins. The results were recorded from photographs on graph paper. The retention factor was calculated in places where there was the appearance of white spots.

For the statistical analysis of retention factors, the experiment employed a completely randomized design with two replications, using the software Sisvar ${ }^{\circledast}$ according to Ferreira ${ }^{7}$. The factorial schemes used were the three species and three plant parts studied. For the retention factor, we used the t-test to detect differences between treatments and the $t$-student (LSD) $(p$-value<0.05) for comparison of means.

From the analysis of chromatography, it was possible to detect the presence of white smudges for this purpose, which represents qualitatively the inhibition of acetylcholinesterase, as the methodology used was based on the cleavage of 2-naphthyl acetate by acetylcholinesterase to form the 2-naphthol, which reacts with Fast Blue $\mathrm{B}$ to generate the diazonium purple coloration ${ }^{2}$. The presence of enzyme inhibitors was observed mainly in flowers (Figure 1), but they were also detected with lower intensity on the branches (Figure 2). The leaves showed no inhibitory action of the enzyme (Figure 3).

The flowers are both sinks of organic compounds on macro and micronutrients ${ }^{8}$, and it is well known that the secondary compounds, potential inhibitors of acetylcholinesterase, physiologically act in plant defense against herbivores, as attractive to pollinators, and hormones used between individuals of the same species for different purposes $^{3}$.

These factors have great relevance in an attempt to justify the higher prevalence of secondary compounds in the flowers, as in this experiment, the samples were collected during the flowering season of the species of Bauhinia. As the branches are the aerial structure of a tree, they have the lowest concentration of micronutrients and secondary compounds because they play major roles in the support,

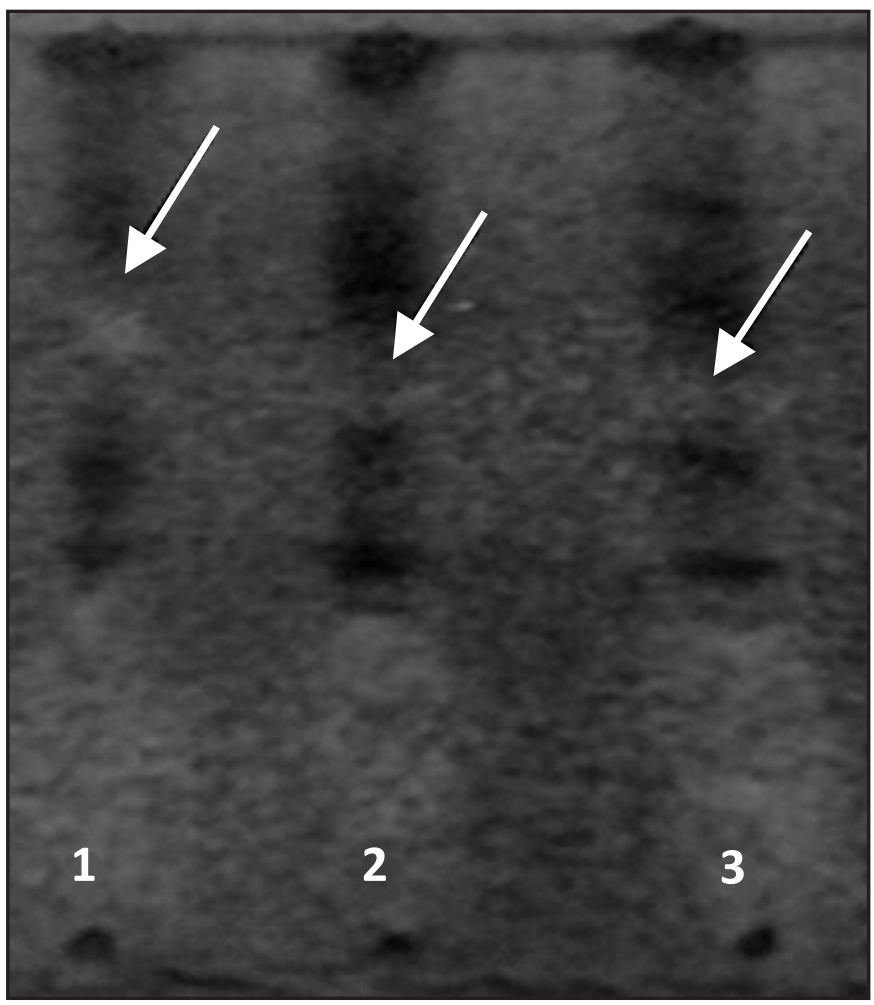

FIGURE 1 - Inhibition of acetylcholinesterase from extracts of flowers: Bauhinia ungulata (1), Bauhinia variegata (2), and Bauhinia variegata candida (3). transport, and storage of the leaves, flowers, and roots9. In this context, it should be argued that the enzyme inhibitors reported in the business are possibly present in this structure being in the transport process.

Studies have shown that the values of secondary compounds can vary significantly between mature leaves and young leaves; the latter has shown higher concentrations of the compounds, and this happens

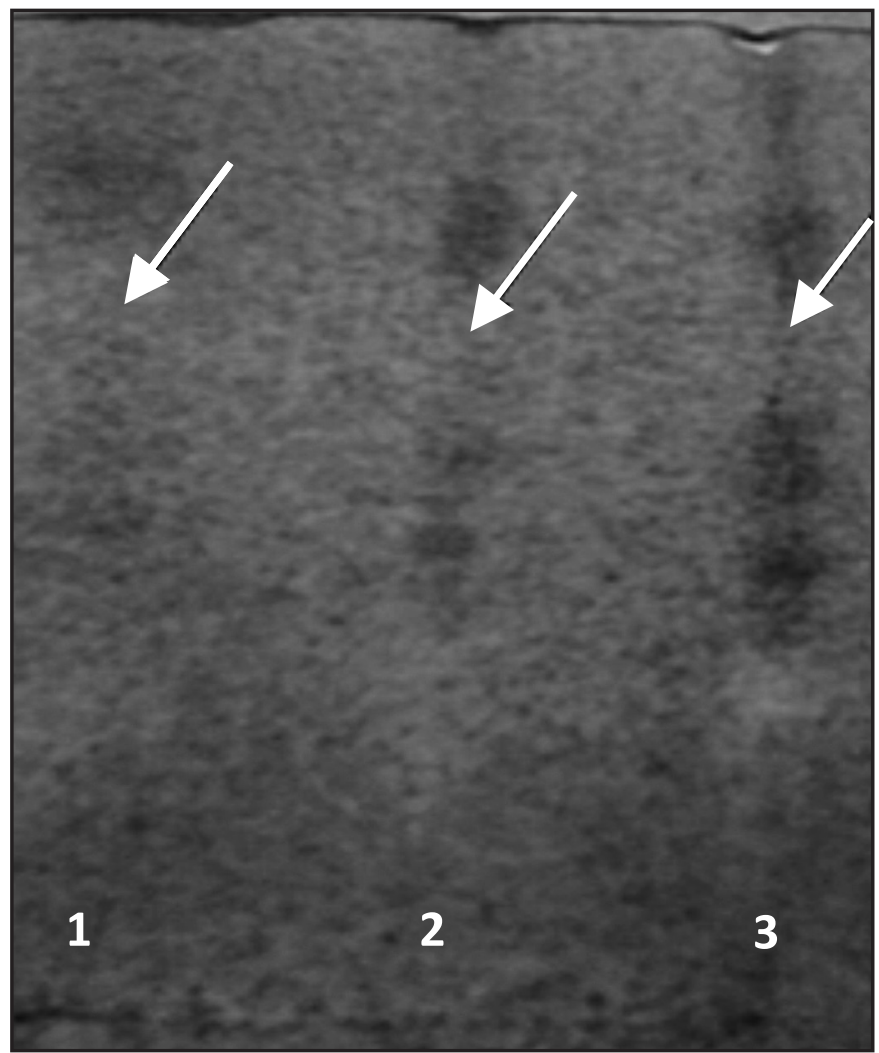

FIGURE 2 - Inhibition of acetylcholinesterase from extracts of stems: Bauhinia ungulata (1), Bauhinia variegata (2), and Bauhinia variegata candida (3)

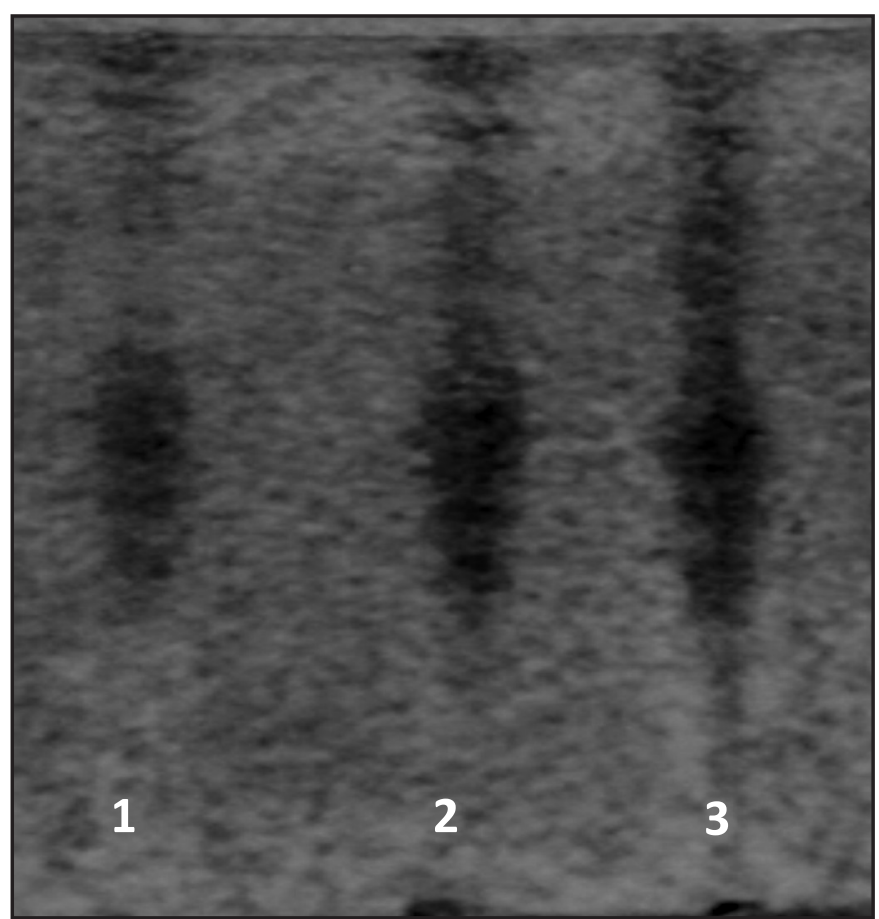

FIGURE 3 - Inhibition of acetylcholinesterase from extracts of leaves: Bauhinia ungulata (1), Bauhinia variegata (2), and Bauhinia variegata candida (3) 
due to translocation of substances to other tissues as growth leaves ${ }^{10}$. When collecting leaves, we selected those with the larger aim, and we believe that this choice may have influenced the negative results reported in the leaves.

Shown in Table $\mathbf{1}$ are the means of the retention factors of the species surveyed. Based on the interpretation of the $t$-student (LSD), statistical values do not differ to a nominal level of 5\% within the body between the species. However, there is an increasing statistical difference between the $\mathrm{Rf}$ for the organs of B. ungulata.

TABLE 1 - Retention factor (Rf) calculated between specimens and between vegetable organs of Bauhinia.

\begin{tabular}{lccc}
\hline \multirow{2}{*}{ Plants } & \multicolumn{3}{c}{ Retention factor (Rf) } \\
\cline { 2 - 4 } & leaves & branches & flowers \\
\hline Bauhinia variegata & $0.00 \mathrm{aA}^{*}$ & $0.12 \mathrm{aA}$ & $0.31 \mathrm{aA}$ \\
\hline Bauhinia variegata candida & $0.00 \mathrm{aA}$ & $0.26 \mathrm{aA}$ & $0.31 \mathrm{aA}$ \\
\hline Bauhinia ungulata & $0.00 \mathrm{aA}$ & $0.12 \mathrm{aA}$ & $0.46 \mathrm{aB}$ \\
\hline
\end{tabular}

Note: ${ }^{*}$ Means followed by the same lowercase letters in the column and uppercase letters on the line do not differ by t-student (LSD) at a nominal level of significance of $5 \%$.

Currently, it is known that the genus Bauhinia has mainly alkaloids and phenolic compounds in its constitution ${ }^{10}$. Even some studies on cognitive function, related to inhibiting the enzyme acetylcholinesterase are the alkaloids, several studies have also been emphasized to the flavonoids and saponins, because mainly tonic properties stimulant, purifying and immune atioxidante as treatments for important degenerative disorders.

It is, therefore, suggested that in-depth reviews of the chemistry of the flowers of Bauhinia ungulata be performed to elucidate the secondary compounds and to quantify the inhibition. From the results of the statistical analysis, we conclude that the extract of the flowers of Bauhinia ungulata, taken within the flowering period, is the most suitable to serve as a basis for further studies on this inhibition.

\section{ACKNOWLEDGMENTS}

To the technicians Conceição Coelho and Madson Camargos for the aid in the execution of the project.

\section{CONFLICT OF INTEREST}

The authors declare that there is no conflict of interest.

\section{FINANCIAL SUPPORT}

PSG has a student fellowship from the Fundação de Amparo à Pesquisa do Estado de Minas Gerais (FAPEMIG).

\section{REFERENCES}

1. Luzardo AR, Gorini MISPC, Silva APSS. Características de Idosos com Doença de Alzheimer e seus cuidadores: uma série de casos em um serviço de neurogeriatria. Texto Contexto Enfermagem 2006; 15:587-594.

2. Moraes LT. Prospecção de substâncias ativas de Serjania erecta Raldk como estimulantes da memória. [Master's Thesis in Biotechnology]. [Ribeirão Preto]: Universidade de Ribeirão Preto; 2008. 69 p.
3. Santos FV. Avaliação da Mutagenicidade in vivo e in vitro de compostos obtidos de plantas nativas do cerrado. [Doctoral Thesis in Clinical Analysis]. [Araraquara]: Faculdade de Ciências Farmacêuticas; 2006. 167 p.

4. Cechinel Filho V, Silva KL. Plantas do Gênero Bauhinia: Composição química e potencial farmacológico Quim Nova 2002; 25:449-454.

5. Caetano ACS. Extração de antioxidantes de resíduos agroindustriais de acerola Brazilian J Food Technol 2009; 12:155-160.

6. Souza WM. Estudo químico e das atividades biológicas dos alcalóides indólicos de Himatanthus lancifolius (Muell. Arg.) Woodson, Apocynaceae - (Agoniada) [Doctoral thesis in Pharmaceutical Sciences]. [Curitiba]: Universidade Federal do Paraná; 2008. 173 p.

7. Ferreira DF. Análises estatísticas por meio do Sisvar para Windows versão

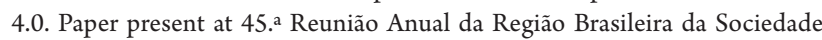
Internacional de Biometria; 2000; São Carlos (SP), Brazil.

8. Malavolta ES, Leão HC, Oliveira C, Lavres Júnior J, Moraes MF, Cabral CP, et al Repartição de nutrientes das flores, folhas e ramos da laranjeira cultivar Natal. Rev Bras Fruticultura 2006; 28:506-511.

9. Silveira AO. Anatomia vegetal. Curvelo: Faculdade de Ciências de Curvelo. Departamento de Ciências Biológicas; 2004.

10. Maia Neto M, Andrade Neto M, Braz Filho R, Lima MAS, Silveira ER. Flavonoids and alkaloids from leaves of Bauhinia ungulata L. Biochem Systematics Ecol 2008; 36:227-229. 